Short communication

\title{
Studies on the mitogenic effect of transferrin by membrane signal transduction
}

\author{
LEUNG TM*, PL LIM * and TT LOH*1 \\ *Department of Physiology and ${ }^{\#}$ Departwent of Microbiology, \\ Medical Faculty, University of Hong Kong, Hong Kong
}

\begin{abstract}
One of the earliest events leading to cell activation and growth is the hydrolysis of inositol phospholipids producing various membrane signals induced by an interaction between growth factors or hormones with their respective receptors on the cell membrane [1]. To demonstrate the mitogenic action of transferrin, our results show that an addition of transferrin to "serum-deprived" rat hepatoma cells produced a rapid but transient rise in inositol 1, 4, 5-trisphosphate $\left(\mathrm{IP}_{3}\right)$ level, and at the same time, an increased intracellular $\mathrm{Ca}^{2+}$ activity and a cytoplasmic alkalinization were observed. These signal transduotions further lend support to the mitogenic nature oftransferrin. In addition, a possible link betwagn the receptor-mediated endocytosis of transferrin with the generation of intracellular signals is discussed herewith.
\end{abstract}

Key words: Transferrin, membrane signal, cell, cell activativon, insitol triphosphate, calcium ion flux.

\section{INTRODUCTION}

One of the main current interests in the field of growth factor induced cell activation is centred on the finding of the identity of the membrane components and their resultant second messengers involved in the coupling of receptor activation with the subsequent amplifier system [1]. Transferrin, a specific iron-binding protein in the plasma, has been well known not only for its iron transport and its facilitation for iron uptake by the receptor-mediated endocytosis process [4], but also for its function as a growth factor [5] to induce cell activation and proliferation. The present study was aimed at investigating if transferrin binding to cells would be translated into a series of membrane signals such as inositol 1, 4, 5-trisphosphate and discylglycerol[6] whose production would demonstrate not only the hyperplastic property of transferrin on cell growth and proliferation but also a

1 To whom correspondence should be addressed. 
Signal transduction reduced by transferrin

correlation between the cytoskeletal events ef endocytosis and the membrane signal transduction.

\section{MATERIALS AND METHODS}

Rat hepatoma cell line ( $\mathrm{RH} 35)$ which had Been in culture in our laboratory for some years, were used for this study. They were grown on $60 \mathrm{~mm}$ petric dish to $80 \%$ confluency and then "serum-starved" in MEM medium for 16 hours before they were activated by an addition of $6.25 \mu M$ rat diferric transferrin (which was prepared by the method of Baker et al. [7]). Activation could be torminated by adding $1 \mathrm{ml}$ of $40 \%$ trichloroacetic acid to the cell suspension at $0^{\circ} \mathrm{C}$ for 20 min followed by centrifugal separation. The supernatant was extracted with water saturated with diethyl ether which was later titrated to $\mathrm{pH}$ 7.0-7.5 with $\mathrm{NaOH}$. Inositol triphosphate $\left(\mathrm{IP}_{3}\right)$ present in the extract was debermined by the D-myo-inositol I, 4, 5-trisphosphate $\left[{ }^{3} \mathrm{H}\right]$ assay system (TRK 1000) purchased from Amersham Inlernational plc, Amersham, United Kingdom.

Galcium ions flux and intracellnlar $\mathrm{pH}$ were measured by fluorescent probes, Quin-2 acetoxymethyl ester[8] and bis (earboxyelhyl) carboxyfluorescein acetoxymethyl ester (BCECF /AM) [9] respectively. Briefly, the serum starved cells cultured on cover glass were loaded with $30 \mu \mathrm{M}$ Quin-2/AM or $6 \mu M$ BOEOF for $30 \mathrm{~min}$ at $37^{\circ} \mathrm{C}$ and then washed twice with assay buffer. They were placed in a $3 \mathrm{ml}$ curvette and their fluorescence was continuously measured with a spectrofluorometer (Hibachi F-4010). For calcium ions measurement, the spectrofluorometer was set at $339 \mathrm{~nm}$ for excitation and at $492 \mathrm{~nm}$ for emission. Calibrabion was performed by lysing the cells with $0.025 \%$ Tribon X-100 and subsequently $0.5 \mathrm{mM} \mathrm{MnCl} \mathrm{M}_{2}$ was added to the lysate. For $\mathrm{pH}$ measurement fluorescence was excited at $490 \mathrm{~nm}$ with emission at $530 \mathrm{~nm}$ wavelength. Aft.or the cells were lysed with Triton, a fixed amount of standard acid solutions were added to record the known values of $\mathrm{pH}$ with a $\mathrm{pH}$ electrode.

\section{RESULTS}

Upon stimulation by diferric transferrin $(6.25 \mu \mathrm{M}), \mathrm{IP}_{3}$ was generabed rapidly in a time course as shown in Fig. 1. A peak value was reached at 2 min. after activation and this was followed by a gradual decline returning to its original resting value after $30 \mathrm{~min}$.

Concurrently with the generation of $\mathrm{IP}_{3}$, a sudden surge in cytosolic calcium ion concentration (Fig. 2) was observed immediately after activation by diferric tansferrin and continued to reach a peak after 5 minutes. In this experiment, approximately $150 \mu \mathrm{M}$ of calcium ions was released into the cytoplasm. However, if the cells were pre-treated with trypsin, transferrin failed to induce such $\mathrm{Ca}^{2+}$ ions mobilization (results are not shown here) indicating that transferrin receptors are essential for this induction and the removal of these receptors by trypsinization will terminate this $\mathrm{Ca}^{2+}$ ion activity.

Hyporphosphorylation of membrane phospholipids was also accompanied by a change in cytosolic $\mathrm{pH}$. That is, when the BCECF-loaded hepatoma cells were activated by transferrin, a slow but marked alkalinization wilh a surge of about $0.10 \mathrm{pH}$ unit was observed wibhin 5 rain. (Fig. 3). Addition of phorbol ester, phorbol myristate acetate 


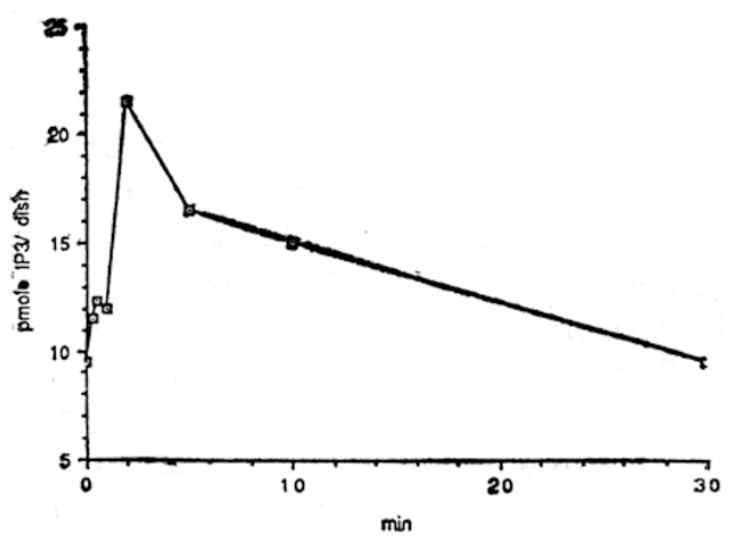

Fig. 1 The time course of inositol 1, 4, 5-triphosphate formation in the monolayer cells of Reuber H35 hepatoma when stimulated by $6.25 \mu M$ rat diferric transferrin. Each dish contained approximately $2 \times 10^{6}$ cells.

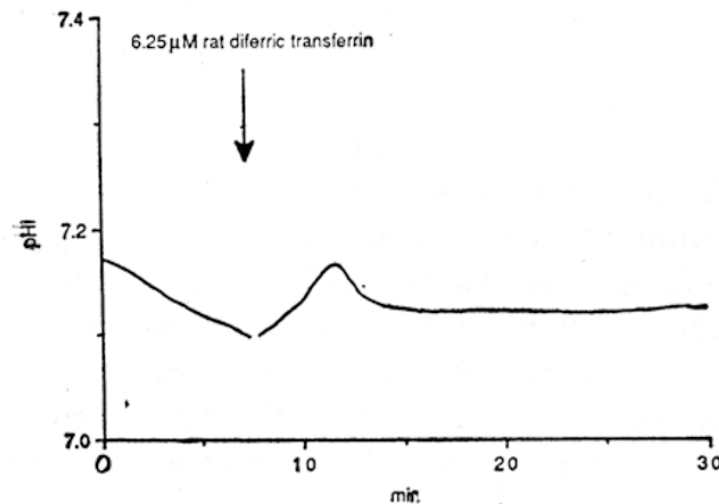

Fig. 3 A continued fluorimetric recording on the changes in intracellular $\mathrm{pH}$ in BCECF-loaded hepatoma cell induced by rat diferric transferrin. Again, when the fall in intracellular $\mathrm{pH}$ which was initially due to the leakage of the florescence probe from the cell, was stabilized, transferrin, as indicated by the arrow, was added.

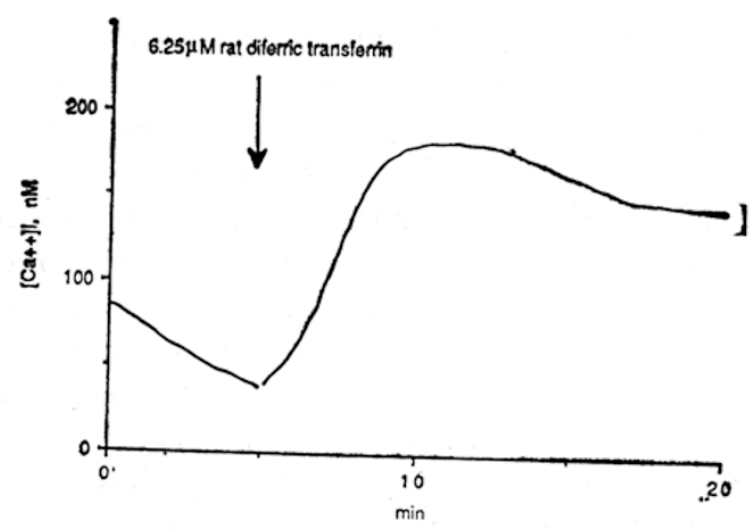

Fig. 2 A continued fluorimetric recording on the changes in intracellular calcium ions in qnin 2-loaded hepatoma cells'induced by rat diferric transferrin $(6.25 \mu M)$. As soon as the fall in fluorescence $\mathrm{w}$ icn is to be expected as a result of the unavoidable leakage of quin -2 from the cell was stabilized, transferrin as indicated by the arrow was added.

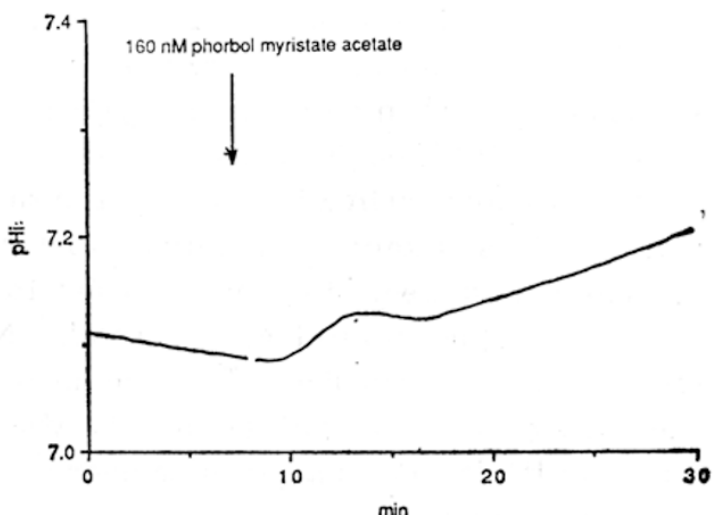

Fig. 4 A continued fluorimetric recording of the change in intracellular $\mathrm{pH}$ in BCECF-loaded hepatoma cells induced by phorbol myristate acetate (160 $\mathrm{n} M)$. As in Fig. 3, the arrow indicates the time when the stimulant was added.

which is an activator of $\mathrm{PKC}[6]$ in the absence of transferrin, exhibited a similar cytoplasmic alkalinization (Fig. 4).

\section{DISCUSSION}

In the present study, the binding of transferrin to the surface reespt ors in "serumdeprived" rat hepatoma induced an immediate surge in intracellular inositol trisphosphate 
Signal transduction reduced by transferrin

$\left(\mathrm{IP}_{3}\right)$ formation. This generation of $\mathrm{IP}_{3}$ was followed closely by a sudden rise in intracellular $\mathrm{Ca}^{2+}$ level and an increase in cytosolic $\mathrm{pH}$. These observations suggest that transferrin can induce membrane signal transductions similar to those induced by growth factors prior to cell activation processes. These observations will lend support for the mitogenic function of transferrin during cell culture or growth[5]. Although the present study has not provided specific evidence on the signalling pathways involved in transferrin's mitogenicity, it is not illogical to deduce from the massive documents on the generation of inositol trisphosphate that it is likely to be derived from the rapid hydrolysis of the phosphoinositides to generate both $\mathrm{IP}_{3}$ and DG[6]. The inositol trdsphosphate, released into the eytosol, will mediate a fast and transient release of $\mathrm{Ca}^{2+}$ ions from both the in tracellular and extracellular stores [6] while DG will activate protein kinase $\mathrm{C}$ and the $\mathrm{Na}^{+} / \mathrm{H}^{+}$ exchange system[1,2]. As far as signal transduction is concerned, cell growth and proliferation is generally preluded by an atkinalization of the cytoplasmic $\mathrm{pH}$ which is regulated mainly by the $\mathrm{Na}^{+} / \mathrm{H}^{+}$exchanger[9]. The observation that the phorbol esters, which are thought to act through protein kinase $\mathrm{C}[6]$, can increase $\mathrm{pH}$ in $\mathrm{RH} 35$ hepatoma cells, suggests that diacylglycerol may be responsible for activating the amiloride-sensitive $\mathrm{Na}^{+} / \mathrm{II}^{+}$carrier system. An increase in cylosolic $\mathrm{pH}$ induced by transferrin supports not only the mitogenieity of transferrirn but also implicates a possible connection between the DG and $\mathrm{Na}^{+} / \mathrm{H}^{+}$antiporter system although the latter requires further investigation.

In addition to the mitogenic effect, the selective binding of transferrin which induces a rapid receptor-mediated endocytotic process with a similar time course has also been well demonstrated in our laboratory[10]. Based on the fact that phorbol esters can alter the cytoplasmic $\mathrm{pH}$ through the action from protein kinase C (PKC) [2] prior to hyperphosphorylation of transferrin receptors [3] and that transferrin mimics the effects of phorbol esters (Fig. 4), it is likely that any transferrin-induced cytoskeletal changes leading to endoytosis and recycling of transferrin-receptors may be initiated from a common membrane signal transduction process. Nonetheless, further work will be required to confirm such correlation. In conclusion, our preliminary study here can offer a capacitating model for further investigation into whether transferrin will concomitantly exert a multiple role as an iron carrier as well as a signal inducer for both mitogenie and endocytotic process.

\section{ACKNO WLEDGEMENT}

We are indebted to Mr. W. B. Wong for his excellent technical assistance. This work was supported by the University of Hong Kong Research Funds.

\section{REFERENCES}

[ 1 ] Rozengurt, E and Mendoza SA. Early stimulation of $\mathrm{Na}+-\mathrm{H}+$ antiport, $\mathrm{Na}+-\mathrm{K}+$ pump activity, and $\mathrm{Ca}^{2+}$ fluxes in fibroblast mitogenesis. In: Mandel LJ, Benes DJ eds. The role of membranes in cell growth and differentiation. Acad Press Inc London 1986; 27: 163-191.

[ 2 ] May WS, Sahyoun N, Jacobs S, Wolf M and Cuatrecasas P. Mechanism of phorbol diester-induced regulation of surface transferrin receptor involves the action of activated protein kinase $\mathrm{G}$ and an intact cytoskeleton. J Biol Chem 1985; 260: 9419-9426.

[ 3 ] May WS, Jacobs S and Cuatrecasa P. Arssociation of phorbol ester-induced hyperphosphorylation and reversible 
Leung TM et aL.

regulation of transferrin membrane receptors in HL 60 cells. Proc Natl Acad Sci 1984; 81: 2016-2020.

[ 4] Hanover JA and Dickson RB. Transferrin: receptor-mediated endocytosis and iron delivery. In: Pastan I and Willingham MC, eds. Endocytcsis, Chapter 5. Plenum New York 1985: 131-161.

[ 5] Dillner-Centerlind ML, Hammarstrom S and Perlmann P. Transferrin can replace serum for in vitro growth of mitogen-stimulated T lymphocytes. Eur J Immunel 1779; 9: 942-948.

[ 6 ] Berridge MJ. Inositol triplhosphate and diacylglycerol: two interacting second messengers. Ann Rev 1987; 56:159 $-193$.

[ 7 ] Baker E, Shaw DC and Morgan EH. Isolation and characterization of robbit serum and milk transferrins. Evidence for difference in sialic acid content only. Biochem 1968; 7: 1371-1378.

[ 8 ] Rink T J, Tsien RY and Pozzan T. Cytoplasmic pH and free $\mathrm{Mg}^{2+}$ in lymphocytes. J Cell Biol 1982; 95 : $189-196$.

[ 9 ] Nadshus IH. Regulation of intracellular pH in eukaryotic cells. Biochem J 1988; 250: 1-8.

[ 10 ] Lon TT, Chau RYY and Fong WF. Effects of spermine on transferrin and iron uptake by reticulocytes: 1. Action on the endocytic uptake of transferrin. Cell Biol Intern Reports 1985; 9' 229-235.

\section{Received 9-8-1990. Revised 12-5-1990. Accepted 13-6-1990.}

